\title{
Correction to: UV-C pre-adaptation of Salmonella: effect on cell morphology and membrane fatty acids composition
}

\author{
Lobna Maâlej ${ }^{1}$ - Abdelwaheb Chatti ${ }^{1}$. Sana Khefacha ${ }^{1} \cdot$ Kloula Salma $^{1} \cdot$ Davide Gottardi $^{2} \cdot$ Lucia Vannini $^{2}$. \\ Maria Elizabetta Guerzoni ${ }^{2} \cdot$ Abdennaceur Hassen $^{1}$
}

Published online: 12 February 2022

○) Springer Nature B.V. 2022

\section{Correction to: \\ World J Microbiol Biotechnol (2014) 30:925-930 \\ https://doi.org/10.1007/s11274-013-1510-2}

Following publication of the original article [1], the author reported an error in processing given name and family name of the authors Davide Gottardi and Maria Elizabetta
Guerzoni. The correct given name and family name of the authors are:

Given name: Davide, Family name: Gottardi

Given name: Maria Elizabetta, Family name: Guerzoni

Publisher's Note Springer Nature remains neutral with regard to jurisdictional claims in published maps and institutional affiliations.

The original article can be found online at https://doi.org/10.1007/ s11274-013-1510-2.

Abdelwaheb Chatti

chattiabdel@yahoo.fr

1 Laboratoire de Traitement des Eaux Usées, Centre des

Recherches et des Technologies des Eaux (CERTE),

Technopole Borj Cédria, BP 273, 8020 Soliman, Tunisia

2 Department of Food Science, Alma Mater Studiorum, University of Bologna, Via Fanin 46, 40127 Bologna, Italy 